The $5^{\text {th }}$ Rajabhat University National \& International Research and Academic Conference (RUNIRAC V)

\title{
The Existence of Gamelan, Kampong, and Mount Krakatoa Eruption Fundraising in Amsterdam Exhibition in 1883
}

\author{
Asep Nugraha \\ Karawitan Department ISBI Bandung, Jalan Buahbatu 212, Bandung, West Java, Indonesia, 40265 \\ Corresponding Author's Contact: kangasepnugraha@gmail.com, +6281283584288
}

\section{Abstract}

In 1883, the gamelan, village, and socio-cultural activities of the Dutch East Indies were publicly displayed directly at the De Internationale Koloniale en Uitvoerhandel Tentoonstelling event in Amsterdam. The Dutch East Indies, represented by a group from Parakan Salak, Sukabumi - West Java introduced colonial land cultural entities for six months. Even though they had to deal with the ethnocentrism view that is still strong in European society. However, the performance was carried out by them as good as possible. Their success was accepted by Amsterdam people when there was an eruption of Mount Krakatoa in the Dutch East Indies. The European community and the group of Parakan Salak work together to raise funds for Mount Krakatoa victim. One of them was through a charity performance that presents gamelan and dances. The existence of the art of the colonial land community was able to gather unity to achieve a single goal, there was no more caste differences, between the colonialist and the people of the colony. All are united in the name of humanity.

Keywords: exhibition, fundraising, gamelan prakansalak.

\section{Introduction}

At De Internationale Koloniale en Uitvoerhandel Tentoonstelling in Amsterdam 1883, Parakan Salak tea plantation had occupy an exhibition stand that sells tea commodities accompanied by unique promotional methods. The visitors tasted the tea while enjoying the visualization that led them to be in a colony, where the tea plant was cultivated. The visualization was formed through the performances of gamelan, dances, and life activities of indigenous peoples (residents of Parakan Salak) which were directly appreciated at the exhibition stand in Amsterdam

This paper tries to recount the journey of the Parakan Salak group at the De Internationale Koloniale en Uitvoerhandel Tentoonstelling in Amsterdam event in 1883. The event is considered the toughest challenge for the Parakan Salak plantation group to perform in front of the European public. At that time the stigma of European society still under estimated on the culture of the colonized people, considered primitive and backward. However, the stigma can be brushed aside by the Parakan Salak group during the exhibition.

The success of the group was re-presented at the next international trade exhibition. A number of literatures inform that the Parakan Salak group held the next exhibition at the Exposition of Universelle De Paris in 1889 [1], and the World's Columbian Exposition in Chicago, USA, in 1893 [2].

The study method was carried out by tracing a number of literatures that recorded the Parakan Salak group in Amsterdam in 1883. The result of literature research are then processed and compiled into papers. 
The $5^{\text {th }}$ Rajabhat University National \& International Research and Academic Conference (RUNIRAC V)

\section{Result}

A.W. Holle, the owner of Parakan Salak plantation

Ardriaan Walraven Holle is the owner of the Parakan Salak tea plantation located in Sukabumi, West Java. He is a Dutchman who is familiar with Sundanese culture, starting since his arrival in the Dutch East Indies (Indonesia) in 1844, when he was 12 years old [3]. In the Dutch East Indies Holle lived at the residence of his mother's elder brother Williem van der Hucht, who had founded the Parakansalak tea plantation company [3]. In the end the plantation was managed by A. W. Holle, almost for the rest of his life. He began as the administrator of his Uncle, van der Hucht, and subsequently became the administrator and owner of the plantation [3].

A. W. Holle is a plantation administrator who is 'close' to indigenous workers. Even everyday he wears Sundanese traditional clothing [4]. Its proximity to Sundanese culture is his ability to play Sundanese gamelan, especially rebab [2] [3]. In addition AW Holle with his brother, Karel Frederik Holle, made a teaching book for schools in Sundanese Priangan entitled Kitab Pangadjaran Basa Soenda (1849/1850) and Tjarita koera-koera djeung monjet (1851), printed in the Netherlands [5].

No wonder when promoting the Parakan Salak tea plantation in the European market, A.W. Holle includes Sundanese cultural entities. He wanted to share his experiences and beauty with the culture in the colonies, between Eastern cultures that were different from the West. With no half-hearted indigenous employees from the plantation who used to play gamelan were brought to Europe with dancers, as part of the promotion of the plantations there. It can indeed that the idea pioneered by A.W. Holle is speculative, because its success is very minimal considering that Europeans still under estimated on the socio-cultural life of the people in the colonies at that time. They view it as barbaric, primitive and ancient.

Twenty countries participated in the International Trade and Export Exhibition (De Internationale Koloniale en Uitvoerhandel Tentoonstelling in Amsterdam) which was opened on May 1, 1833 attended by the kings and queens of the Netherlands. The Parakan Salak plantation brought 60 villagers who became workers in plantations, horses, buffaloes and tigers, to fill out exhibition stands that lasted for six months, from May to October [6].

During the exhibition, the tea plantation group presented a realistic impression of the social and cultural life of the people in the colony land. Realistic impressions were created by building villages (called kampong), which are inhabited by people / families from the Parakan Salak tea plantation. At the location of the new village, plantation workers live their lives like in their hometowns. The difference is they live in the middle of a European-style concrete building that is paradoxical with kampong architecture made of wood and bamboo. This paradigm occupied a unique and exotic Parakan salak group for visitors in the exhibition. Their daily activities are recorded in the Dutch report: zoalsvlechtenvan hoeden (making headbands), het weven van Indischestoffen (weaving cloth), and het beploegen van steeds hetzelfde akkertje (plowing fields) [6].

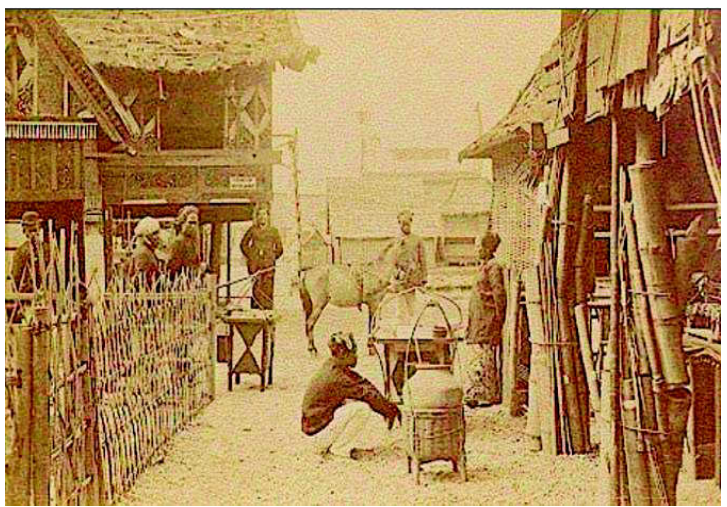

Figure I. Kampong in Amsterdam 1883 [6] 
The $5^{\text {th }}$ Rajabhat University National \& International Research and Academic Conference (RUNIRAC V)

\section{Parakan Salak Gamelan Performance}

In the afternoon the Parakan Salak tea workers play the gamelan to accompany a number of dances. Whereas on the morning to noon, the musicians and dancers play the role of village residents who are appreciated by the visitors who want to see the daily social and cultural activities of the indigenous people in the Dutch East Indies colony [6].

Gamelan players and dancers are recorded in the Dutch report. Their faces are shot by the camera. They were written as Sundanese brought by the Parakan Salak plantation. Only one Javanese was contracted by the Parakansalak plantation, he was Sonto Taroeno, a dalang (puppeter) from Surakarta. The dancers are Amsa and Eno came from Tjitjoeroeg (Cicurug) Sukabum and Semani came from Buitenzorg (Bogor). While the chairman of the gamelan group from Parakansalak is Sidin Ahoem (fiddle player) and other musicians from Parakan Salak Sukabumi are Rimboe, Wadi, Ansissin, Empang, Saminan, Jamam, Maih, Ueta, Andut, Salir and Elor ([6].

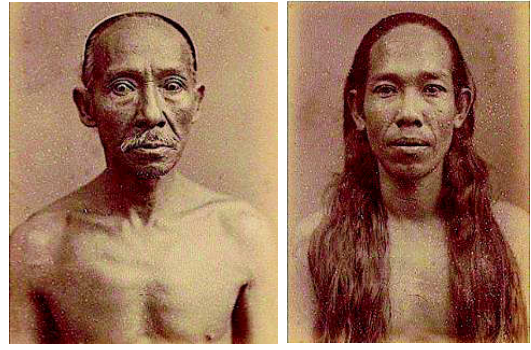

Figure 2: Sonto Taroeno \& Sidin Ahoem [6]

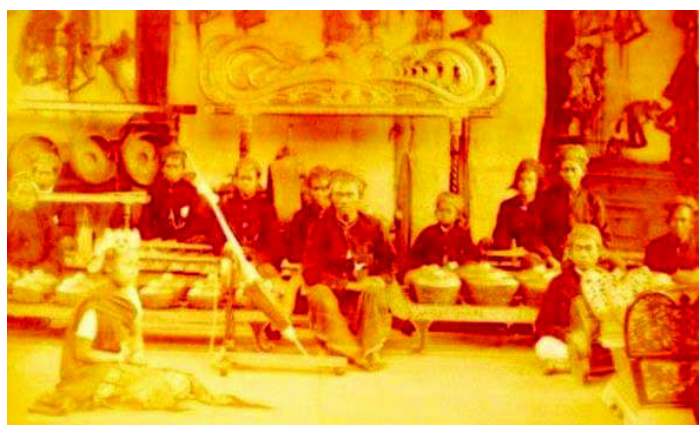

Figure 3. Gamelan in exhibition 1883 [6]

At the opening of the exhibition, the Parakan Salak gamelan was used to accompany the Dutch national anthem, Wilhelmus, which was diatonic in scale, sung by indigenous groups [7]. This was the idea of Daniël Veth who thought it would be better if the Dutch King heard Wilhelmus's song sung by Dutch East Indies People with the their language and accompaniment of their musical instruments [6] Imagine a gamelan with a pentatonic tone used to accompany a diatonic song. It is certain that there are shortcomings because the limitations of the notes on the gamelan are dealt with by the musicians by replacing the 'unreachable' tone with other notes on the gamelan which are considered to be able to represent or sound harmonious.

The Parakan Salak group in Fundraising for the Mount Krakatoa Eruption in 1883

During the excitement of the exhibition, in the Dutch East Indies there was a catastrophic eruption of Mount Krakatoa on August 27, 1883, causing 36,000 deaths and destruction due to fire, rocks, and mud to hit the land inhabited by the population. The eruption of the volcano in the Sunda Strait caused a large tsunami that swept the coast of the western part of Java and eastern Sumatra.

The news was received by the Dutch authorities in Amsterdam via radio telegraph, followed by Studentengezelschap India Orientalis to raise funds for the Indies at Stadsgehoorzaal Laiden, by bringing 16 people to the Parakan Salak plantation group at an exhibition in Amsterdam. They are included in fundraising performances [6] The gamelan stored in the Ethnographisch Museum is used in the show. The Parakan Salak group performed new material that had not been shown during the exhibition, namely the golék puppet, topéng dance, and angklung, which lasted all night long until six in the morning.

The reviews of newspaper informs the existence of Parakansalak personnel from the exhibition site in Amsterdam who played a role in the disaster fundraising for Krakatoa in Leiden. The 
The $5^{\text {th }}$ Rajabhat University National \& International Research and Academic Conference (RUNIRAC V)

review concerns art content with its artists: $D e$ wajang karoesjil (golèq): Negri Siloeman werd in Leiden vertoond door and dalang (Koens Toekang rebab) Sidin uit de Prijangan. De wajang poerwå door den mandoer pgnijagan Sonto Taroeno, uit Surakarta. (Wayang krucil (golèk) play of the Country Demon is displayed in Leiden by dalang (rebab player) Sidin from Priangan, Wayang purwa by mandoer pgnijagan Sonto Taroeno, from Surakarta).

The mask dance that was shown was also reviewed by journalists based on their 'perception' as Europeans, and namely the impressive form of pantomimes (pantomime) for the public of Leiden, where dancers from Amsterdam (Parakansalak) appeared in the section [6]. After the break, the audience enjoys angklung and a game of congkak or dikon. While angklung is played, Amsa and Eno, two ronggeng (dancer) members play dakon [6].

\section{The Response of the Amsterdam People}

The success of the Parakan Salak plantation at De Internationale Koloniale en Uitvoerhandel Tentoonstelling in Amsterdam in 1883 was considered speculation. Appreciation of European society in responding to the colonial culture is still lacking. The reason is that ethnocentric understanding that lowers the culture of other nations is still "strong" in Europe in the 19th century [8].

Ethnocentric understanding in Europe was perceived by the Parakan Salak group at the beginning of the arrival at Amsterdam, through 'slanted' comments that appeared in a number of newspapers. It was dealt with by slowly explaining the cultural content of colonies. One of them is elaborating Eastern and Western cultural entities, implemented in pendhapa buildings as the center of exhibition activities, which are Middle Eastern and European architectural styles. Characteristics of the building are maintained as in the locus, which is open (without walls) and supported by poles and functioned as a place for performing arts.

Not far from the location was established indigenous villages in the Dutch East Indies such as at its locus, from wood and bamboo materials and thatched roofs. The settlement might be represented as a primitive and backward building. However, the implementation for six months provided a considerable time span for the European public to recognize the situational culture of colonized land communities intensely. Whether you want it or not, like it or not, sooner or later they are accustomed to the contrasting views of the culture. Even among the visitors there were those who participated weaving cloth, making headbands, and plowing the fields with buffalo. They also danced with the ronggeng accompanied by a gamelan from Parakansalak at the pendhapa.

F.W. Van Eeden, director of the Koloniaal Museum in Haarlem, wrote a very popular reflection on Nieuws van den Dag (1883). He not only discussed knowledge and comments about the colonial world, but the events of the Parakansalak group along with culture were shown at international exhibitions as a wonderful momentum for Europeans to recognize the character of the Indies people who appeared pure. Eeden spoke softly about the artistic taste of the people of the Dutch East Indies and asked the readers to look at the objects in the showcase, like the following quote:

Pay attention to the soft colors, though dull, but are visually pleasing compared to aniline paints in Europe which appear to be 'hard', 'scream', and 'sharp' for the eyes. These colors are taken from vegetable ingredients; red from stoklak (hardened tree trunks due to lice parasites), root of Mangkudu tree, and sapphire wood; rose from safflower; yellow from Curcuma (temu lawak); Indigo, chocolate from soybeans Bast. These are natural colors, such as those in their landscapes, and in the 
The $5^{\text {th }}$ Rajabhat University National \& International Research and Academic Conference (RUNIRAC V)

use of ornaments, natural laws are followed, which limits strange colors to the smallest surfaces.

Eden's outpouring of nature in the sociocultural activities of the village people at the exhibition resulted in a synthesis of the discourse of Western progress versus indigenous primitivism from the colony. Eaden quips Europeans that no longer concern to the nature. Contrary to the village community as human protagonists and tools as servants, while Europeans live spoiled lives, because they are sustained by machines and activities by pressing sticks [6].

In short, the village community appears stunning and gives the image (identity) of a nation. That was the missing factor from the European identity as Eeden said: "Our national character is no longer talking about our identity, but the image is damaged because it is oriented to Italy, Rome and Greece. We Europeans are real barbarians" [6].

The existence of the Parakan Salak gamelan during the exhibition took place, it can be said as a pioneer in breaking down the appreciation of Europeans who at that time looked down on indigenous culture (colonized land). In the latest thinking at that time, Western culture and music were considered superior, while gamelan music which was perceived as monotonous and made people sleepy - was seen as the music inferior from the indegenous people [7]. There is a stigma that playing gamelan is something 'down to earth' [7]. In other words, it is the same as playing backward material and back to being primitive.

Only one composer at that time was interested in the existence of the Parakan Salak gamelan. He is Daniel De Lange. Although De Lange commented on the appearance of a gamelan performance called onderschikten (inferior). This was felt when the gamelan accompanied the Dutch national anthem, Wilhelmus. Lange's criticism ended with suggestions that the gamelan brought from Parakan
Salak be replaced by the saléndro gamelan stored in the Leiden Museum [6]. Although De Lange's suggestion, according to the author, actually does not solve the problem of falsic tones according to the size of the diatonic scale. Both pélog and saléndro, they will not correspond to the tones on the diatonic scale, because the different of pitch interval range. But at least the criticism made by De Lange shows the attention of Dutch musicians who appreciate the performances of the Parakan Salak gamelan in Amsterdam and Leiden.

The interesting thing about gamelan activities collaborated with diatonic songs at the De Internationale Koloniale en Uitvoerhandel Tentoonstelling in Amsterdam event is the cross cultural momentum carried out by artists from Parakan Salak. The events that occurred in the past turned out to be repeated and revived in the present, marked by collaborations of gamelan that are crossed with musical instruments from other cultures or in the form of contemporary music compositions.

Many artists claim that the collaboration of gamelan with foreign music is an 'present' event triggered by them. This is understandable because of their ignorance, especially the history of the Parakan Salak gamelan which carved gold ink as accompaniment to Wilhelmus's song, appearing in front of the Dutch king, long before Indonesia's independence, and long before Indonesian composers who claimed it was born.

At the time of the Mount Krakatau eruption charity performance which was held from evening to morning, previously the Dutch liberal daily newspaper, Algemeen Handelsblad (1883) presented negative comments regarding the duration of the show that was too long for the audience in Europe. The reviews are: Eenig denkbeeld, zeg ik; het ware een dwaasheid, te eischen dat de voorstelling in Holland even zoo zou 
The $5^{\text {th }}$ Rajabhat University National \& International Research and Academic Conference (RUNIRAC V)

zijn al eene op Java (some people commented: it was ignorance, equating performances in the Netherlands with the Dutch East Indies). Pessimistic sentiments that doubt on the success of the show were anticipated by the committee by providing music, accommodating Europeans who did not like the Dutch East Indies (Indonesia) performances in order to still be able to contribute to the Krakatau disaster [6].

Apart from that, the Dutch liked gamelan performances and dances from the lands of the Dutch East Indies, and the presence of the Parakan Salak group was seen as contributing to introducing their performing arts internationally. Even the show was able to collect fund in very large amounts. After the implementation of a charity concert, reviews on newspapers changed 180 degrees. They wrote: De verslaggever besloot zijn relaas met de wens: 'De opbrengst voor de slachtoffers in Indië moge ruim zijn, wij twijfelen daar niet aan, want de zaal was geheel bezet (the report concluded:' The results for victims in the Indies might big, we don't doubt that, because the place of the charity show is really filled) [6]. Once again, the Parakan Salak group with the gamelan and the performing arts entity that it carried had distorted the views of Europeans to recognize the beauty of culture and the arts of the colonies.

\section{Conclusion}

De Internationale Koloniale en Uitvoerhandel Tentoonstelling in Amsterdam 1883 is the momentum for the Parakan Salak group to provide an image (identity) of the existence of the Indonesian in the eye of the world. Although at that time Indonesia was still colonized by foreign nations and the name Indonesia was still known as the Dutch East Indies.

During the exhibition event, the plantation group was able to reverse the oblique comments regarding cultural backwardness in the colonies, as an exotic and natural value. The socio-cultural activities of the people in the colonies that were presented by kampong, gamelan and art opened the eyes of the European people. Even after that they flocked to study the socio-cultural activities of the people in the colonies.

One of the interesting things about the existence of the Parakan Salak group in the $D e$ Internationale Koloniale en Uitvoerhandel Tentoonstelling event is they occurred during the Krakatoa eruption disaster. Through the display of artistic performances from the colonies, it turns out that all nations, ethnic group, colonizers and colonized communities can unite in unity to achieve a single goal, to raise funds for humanity who is coming to grief due to disaster. That is Unity in diversity.

\section{References}

[1] Fauser, A. (2005). Musical Encounters at the 1889 Paris World's Fair. Rochester: University of Rochester Press.

[2] Ross, L. M. (2016). The Encoded Cirebon Mask: Materiality, Flow, and Meaning Along Java's Islamic Northwest Coast (Studies on Performing Arts \& Literature of the Arts \& Literature of the Islamicate World). Boston: Brill Academic Pub.

[3] Berg, N.V.D. (1991). Een mijner beste Indische vrienden De relatie tussen Cd. Busken Huet en A.W. Holle. Indische Letteren: Deel 3. Pp 115-128.

[4] Kunto, H. (1986). Semerbak Bunga di Bandung Raya. Bandung: PT Granesia.

[5] Moriyama, M. (2005). Sundanese Print Culture and Modernity in $19^{\text {th }}$ Century West Java. Singapore: Singapore University Press.

[6] Terwen, J.W. (2003). De Lange En De Gamelan: Een negentiende-eeuwse ontmoeting tussen Oost en West. Thesis. Universiteit van Amsterdam.

[7] Barendregt, B., and Bogaerts, E. (2016). Merenungkan Gema Perjumpaan Musikal Indonesia-Belanda. Jakarta: Yayasan Pustaka Obor Indonesia.

[8] Nakagawa, S. (2000). Musik dan Kosmos: Sebuah Pengantar Etnomusikologi. Jakarta: Yayasan Obor Indonesia 